\title{
Long-Term Effects of Weed Control With Picloram Along a Gradient of Spotted Knapweed Invasion
}

\author{
Yvette K. Ortega ${ }^{1}$ and Dean E. Pearson ${ }^{2}$ \\ Authors are ${ }^{1}$ Ecologist and ${ }^{2}$ Research Ecologist, Rocky Mountain Research Station, US Department of Agriculture Forest Service, 800 E Beckwith Ave, \\ Missoula, MT 59801, USA.
}

\begin{abstract}
Broadleaf herbicides are commonly used in rangelands to suppress exotic weeds and release native communities from negative impacts of invasion. However, few studies have comprehensively evaluated treatment effects on differing community components across a gradient of initial invasion levels. We conducted a 6-yr experiment within grasslands of western Montana to measure localscale effects of a broadcast application of picloram on 1) cover of the target invader, spotted knapweed (Centaurea stoebe L.), 2) prevalence of native functional groups, and 3) the secondary invader cheatgrass (Bromus tectorum L.) at differing initial levels of knapweed invasion. Treatment effectively suppressed knapweed, with cover in treated vs. control plots reduced by $>60 \%$ in the sixth posttreatment year. Treatment also appeared to alleviate knapweed's impacts on native perennial grasses, but only at the highest initial level of invasion, where cover of this group increased by $>30 \%$ in treated vs. control plots to equal levels associated with noninvaded plots. In some cases, treatment appeared to exacerbate knapweed's impacts on native forbs. At the no-invasion level, perennial forb cover declined by $>20 \%$ in treated vs. control plots to match values associated with moderate or high levels of invasion, but these treatment effects were minimal at the latter invasion levels. Across initial invasion levels, species richness of perennial and/or annual forbs declined by $>20 \%$ in treated vs. control plots. Treatment also promoted increases in cheatgrass cover, although differences between treated and control plots were relatively small by the sixth posttreatment year. Overall, effects of picloram application depended on initial levels of knapweed invasion, largely due to the varying strength of release effects. Selective treatment of invaded patches vs. broadcast applications would reduce side effects of broadleaf herbicide application and increase compatibility with other management measures designed to improve rangeland conditions and restore grassland communities.
\end{abstract}

\section{Resumen}

Los herbicidas para controlar malezas de hoja ancha se utilizan comúnmente en pastizales para controlar las malezas exóticas y liberar de los impactos negativos de la invasión a las comunidades nativas. Sin embargo, pocos estudios han evaluado exhaustivamente los efectos del tratamiento en diferentes componentes de la comunidad a través de un gradiente de niveles iniciales de la invasión. Conducimos un experimento de seis años en pastizales del oeste de Montana para medir los efectos a nivel local de una aplicación aérea de picloram sobre (1) aplicación total a la especie invasora específica "spotted knapweed (Centaurea stoebe L.), y (2) presencia de los grupos nativos funcionales y (3) la planta invasora secundaria el triguillo (Bromus tectorum L) en diferentes niveles iniciales de invasión de knapweed. Los tratamientos controlaron efectivamente knapweed, en las áreas tratadas contra las áreas no tratadas reduciéndolo en más de $60 \%$ en el sexto año después del tratamiento. Los tratamientos también parecen disminuir el impacto del knapweed en los pastos nativos perennes, pero sólo en el nivel más alto al inicio de la invasión, donde la cobertura de este grupo se incremento por más de 30\% en áreas tratadas contra no tratadas a niveles iguales asociados con parcelas no invadidas. En algunos casos el tratamiento pareció agravar el impacto de knapweed en las herbáceas nativas. En el nivel de no invasión, la cobertura de las herbáceas perennes disminuyo en más del $20 \%$ en áreas tratadas contra las parcelas controles para igualar los valores asociados con niveles moderados o altos de invasión, pero estos efectos de tratamiento fueron mínimos al final de los niveles de invasión. En todos los niveles de invasión inicial, el número de especies perennes y/o herbáceas anuales disminuyó en más de un $20 \%$ en parcelas tratadas contra parcelas controles. Los tratamientos también causaron un incremento en la cobertura del pasto triguillo, a pesar de que las diferencias entre las parcelas tratadas y las no tratadas fue relativamente pequeña en el sexto año después del tratamiento. En general, los efectos de la aplicación de picloram dependieron de la invasión inicial de knapweed, en gran parte debido a la variación del poder de la liberación del herbicida. Tratamientos selectivos de áreas invadidas contra aplicaciones aéreas reduciría los efectos colaterales de la aplicación de los herbicidas para hoja ancha e incrementa la compatibilidad con otras medidas de manejo diseñadas para mejorar la condición de los pastizales y restaurar las comunidades de pastizales.

Key Words: broadleaf herbicide, Centaurea maculosa, cheatgrass, exotic plants, grassland restoration, native plant functional groups

\footnotetext{
Research was funded by the Rocky Mountain Research Station, the Bitterroot Ecosystem Management Research Project, the Forest Service Pesticide Impact Assessment Program, and the Joint Fire Sciences Program.

Correspondence: Yvette Ortega, Rocky Mountain Research Station, Missoula, MT 59801, USA. Email: yortega@fs.fed.us

Manuscript received 25 February 2010; manuscript accepted 6 October 2010.
}

\section{INTRODUCTION}

Management efforts in rangelands and other wildlands are increasingly focused on suppressing invasive plants, which have overrun vast areas worldwide (DiTomaso 2000; Mack et al. 2000; Smith et al. 2006). Underlying these efforts is the common assumption that suppression of the target species will 
release desirable vegetation from the negative impacts of invasion (Pearson and Ortega 2009). Thus, weed control tools such as broadleaf herbicides are frequently used to improve rangeland conditions and facilitate restoration of native plant communities (Rice and Toney 1998; Reever Morghan et al. 2003; Travnicek et al. 2005; USDA Forest Service 2007, 2008). Although efforts to assess recovery of plant communities following application of weed control measures are increasing (e.g., Samuel et al. 2008), the traditional focus on evaluating target weed suppression alone, or the response of a limited number of forage species, remains prevalent (Sheley et al. 2006; Smith et al. 2006; Flory and Clay 2009). Therefore, we often lack comprehensive knowledge of the specific effects of weed control measures on plant community components, including the degree of recovery from invader impacts. This knowledge is needed to further development of integrated management strategies for rangeland improvement and restoration.

Spotted knapweed (Centaurea stoebe L., formerly Centaurea maculosa auct. non Lam.) is one of the most widespread invaders of western North American rangelands (DiTomaso 2000). This exotic perennial forb primarily invades grassland communities at low to mid-elevations, where it has been shown to diminish native plant species richness and reduce grass forage for elk (Cervus elaphus) and livestock (Watson and Renney 1974; Sheley et al. 1998; Ridenour and Callaway 2001). In addition, a study examining relationships between spotted knapweed cover and prevalence of native plant groups within grassland communities indicated that perennial forbs were particularly sensitive to spotted knapweed invasion (Ortega and Pearson 2005). Declines in native forbs are a concern given that they not only dominate species diversity in many grasslands, but also play important ecosystem roles, e.g., by promoting resistance to weed invasion (Pokorny et al. 2004, 2005; Rinella et al. 2007) and providing food resources for a variety of wildlife species (Stevens 1966; Mitchell and Smoliak 1971; Crawford et al. 2004).

Broadleaf herbicides such as picloram are the primary means for effective suppression of spotted knapweed and other invasive rangeland forbs (DiTomaso 2000). Broadleaf herbicide applications targeting spotted knapweed have been shown to elevate levels of native perennial grasses (Rice et al. 1997; Rice and Toney 1998; Tyser et al. 1998; Sheley et al. 2000; Ortega and Pearson 2010) and increase foraging activity of elk (Thompson 1996). At the same time, these treatments have been shown to depress native forbs, particularly several prominent perennial species, and to reduce overall species richness (Rice and Toney 1998; Tyser et al. 1998; Sheley et al. 2006; Crone et al. 2009; Rinella et al. 2009; Ortega and Pearson 2010). However, it is unclear how observed effects of broadleaf herbicide application on specific native plant groups compare in magnitude to the baseline impacts of spotted knapweed, making it difficult to evaluate the costs vs. benefits of this control measure. Furthermore, most broadleaf herbicide studies have examined treatment effects averaged across a range of initial levels of the target weed, yet the treatment response may vary at local spatial scales with the invasion level. Notably, release from impacts of the target weed may be greater where invasion levels are initially greater (Ortega and Pearson 2010). Knowledge of local-scale treatment effects would help managers determine which invasion levels to target and which application methods to utilize (e.g., spot spray vs. broadcast spray) for a given set of conditions. We also need better understanding of the longevity of broadleaf herbicide effects to determine optimal application frequencies compatible with restoration measures such as seeding and planting of native species. Most broadleaf herbicide studies considering the response of native species have not examined the persistence of treatment effects beyond $3 \mathrm{yr}$, and two longer-term studies have obtained conflicting results (Rice et al. 1997; Rinella et al. 2009).

Broadleaf herbicide applications targeting spotted knapweed may also cause increases in exotic grasses such as cheatgrass (Bromus tectorum L.). This annual grass is the most widespread invader of Western rangelands, provides poor forage relative to the native species it displaces, and is difficult to control (DiTomaso 2000; Hempy-Mayer and Pyke 2008; Vasquez et al. 2008). A previous study found that suppression of spotted knapweed with broadleaf herbicide elevated cover of cheatgrass, with this effect persisting into the third and final year of sampling (Ortega and Pearson 2010). Another study examining a similar herbicide application documented increases in exotic grasses including cheatgrass, evident in the third and final posttreatment sampling year (Sheley et al. 2006). However, a comparable study found that treatment-induced increases in a related species, Japanese brome (B. japonicus Thunb. ex Murr.), dissipated by the third year following spraying (Rice and Toney 1998). Therefore, the long-term effects of broadleaf herbicide application on problematic exotic grasses and the associated need for mitigation strategies are unclear.

We conducted a long-term study within grasslands of western Montana to comprehensively evaluate effects of a common broadleaf herbicide application on 1) cover of the target invader, spotted knapweed, 2) cover and species richness of three native functional groups: perennial forbs, annual forbs, and perennial grasses, and 3) cover of cheatgrass, the secondary invader. To consider a range of local-scale conditions, pretreatment sampling was conducted in plots at four pairs of sites initially containing variable levels of spotted knapweed and low levels of cheatgrass. Picloram was then aerially applied to one site in each pair, and treatment effects in plots were evaluated at differing baseline levels of knapweed cover for three subsequent years and again at $6 \mathrm{yr}$ posttreatment. This approach allowed us to examine treatment effects as a function of initial knapweed levels in plots and to relate changes in prevalence of native plant groups to baseline declines associated with knapweed invasion in untreated plots.

\section{METHODS}

We studied intermountain bunchgrass communities (Mueggler and Stewart 1980) with scatterings of ponderosa pine (Pinus ponderosa P. and C. Lawson) and Douglas-fir (Pseudotsuga menziesii [Mirbel] Franco), classified as winter range for elk and deer on the Lolo National Forest in western Montana (USDA Forest Service 2001). Study sites were steep, southwestfacing slopes at elevations between $1300 \mathrm{~m}$ and $1700 \mathrm{~m}$, and averaged 10.9 ha \pm 1.45 standard error (SE) in size, with a minimum separation of $>1 \mathrm{~km}$. The dominant native species (i.e., those with highest canopy cover) were arrowleaf balsamroot (Balsamorhiza sagittata [Pursh] Nutt.), a perennial forb, 
and bluebunch wheatgrass (Pseudoroegneria spicata [Pursh] A. Löve), a perennial bunchgrass, with sites also containing $>80$ native herbaceous species (Ortega and Pearson 2005). To control for background ecological factors, sites were paired, with one site ultimately treated with herbicide and the other remaining untreated throughout the experiment (see below). Sites in each pair were selected according to similarities in topography, native vegetation, and invasion status. Two site pairs were "invaded," containing extensive patches of spotted knapweed intermixed with native vegetation, and two pairs were "native," with knapweed infestations in the vicinity but only trace levels on the sites $(<1 \%$ mean canopy cover; Ortega and Pearson 2005). Native sites were included to account for variation in the prevalence of native functional groups within communities not invaded by knapweed, thereby improving measurement of 1) baseline declines correlated with knapweed invasion prior to herbicide treatment (reported in Ortega and Pearson 2005) and 2) the response to herbicide treatment at differing baseline levels of invasion. Cheatgrass was the most common secondary exotic species and occurred at low levels $(<3 \%$ mean canopy cover) on all sites at the onset of the study (Ortega and Pearson 2005).

To capture a range of initial conditions (i.e., levels of spotted knapweed and native taxa) at the local (i.e., plant-neighborhood) scale, $n=52$ permanently marked $0.5-\mathrm{m}^{2}$ plots were systematically distributed at 20-m intervals along four transects oriented perpendicular to the slope and $50 \mathrm{~m}$ apart at each site. Following methods described below, plots were sampled prior to treatment, in 2000, as part of a study documenting relationships between native taxa and spotted knapweed (Ortega and Pearson 2005). Over a 3-d period in fall of 2002, in coordination with active weed management efforts (USDA Forest Service 2001), plots at one site per pair were sprayed with the broadleaf herbicide picloram (Tordon ${ }^{\mathrm{TM}} 22 \mathrm{~K}$ ), broadcast by helicopter at $0.28 \mathrm{~kg} \mathrm{ae} \cdot \mathrm{ha}^{-1}$, the lowest rate recommended for knapweed control (Dow AgroSciences 2001). A 90\% nonionic surfactant designed to enhance spreading of the herbicide over plant surfaces was also applied at a rate of $0.023 \mathrm{~L} \cdot \mathrm{ha}^{-1}$. To minimize harm to native species, treatments were applied in fall when native forbs were largely senescent but knapweed was actively growing (Rice et al. 1997).

Posttreatment sampling was conducted for three growing seasons, 2003-2005, to encompass the typical period of picloram's persistence in the soil, and then repeated in 2008 to examine longer-term effects (Rice et al. 1997). One treated site was resprayed in 2006 and therefore eliminated from analysis of 2008 data. A subset of data from 2003-2005 sampling efforts was used in a separate study documenting short-term effects of the treatment on 1) cover and fecundity of arrowleaf balsamroot and bluebunch wheatgrass, the dominant native forb and grass species, and 2) cover of spotted knapweed and cheatgrass, the primary and secondary invaders (Ortega and Pearson 2010). Here we expand on this previous study by examining treatment effects on native functional groups and major invaders over the long-term study period.

All plant sampling methodology followed Ortega and Pearson (2005). Within each plot, percentage of cover by species was estimated to the nearest $1 \%$ twice per growing season: early during the wet period (May-June) and late during the dry period (July-August). To ensure accuracy and consistency, we marked plot frames to denote $1 \%$ cover increments, and cover estimation was conducted by the same two-person team at all sites in each year. Subsets of species in seven genera (Antennaria Gaertn., Castilleja Mutis ex L. f., Delphinium L., Dodecatheon L., Lupinus L., Penstemon Schmidel, Phacelia Juss.) were treated as morpho-groups because they were difficult to distinguish in the field. Native herbaceous taxa were assigned to the following broad functional groups for analysis: perennial forbs (including one biennial species), annual forbs, and perennial grasses (bunchgrasses and one tuft-forming sedge). We used two variables to measure prevalence per functional group for each plot and year: cover per functional group was derived by summing cover values for constituent taxa in each plot and sampling period then averaging across sampling periods, and species richness per functional group equaled the number of unique taxa recorded in each plot across sampling periods.

\section{Statistical Analyses}

We used SAS to construct mixed effects linear models for all analyses (PROC MIXED; SAS Institute 2004). Because knapweed effects are known to operate at the local scale (e.g., Callaway et al. 1999) and initial invasion levels were expected to affect the response to herbicide treatment (e.g., release effects), we considered the plot as the independent sampling unit $(n=416$ for $2003-2005 ; n=347$ for 2008) while including the site pair $(n=4)$ as a random factor in the models described below. Thus, our inferences are specific to the plot vs. site scale. Spatial covariance parameters testing for autocorrelation among plots within sites did not improve Akaike's Information Criterion scores, so these terms were not included in final models. Dependent variables showed moderate positive skewness, but transformation (square root and log) did not change statistical significance of results. We therefore report results for untransformed variables, noting that models should be robust to minor violation of normality assumptions given large sample sizes (Tabachnick and Fidell 1989).

We used an analysis of covariance approach (SAS Institute 2002) to test for effects of herbicide treatment on native functional groups while accounting for pretreatment invasion conditions, i.e., baseline levels of spotted knapweed cover and native response variables at the plot scale. Posttreatment values of each native response variable in each year were analyzed separately, and differences between treated and control plots, evaluated at differing pretreatment invasion levels, represented overall treatment effects. The model included the site pair as a random blocking factor and the following fixed factors: the pretreatment level of the native response variable (covariate), the main treatment effect (i.e., treated or control plots, nested within the site pair), and the treatment $\times$ pretreatment knapweed cover interaction (covariate fitting separate parameters for treated and control plots). The first covariate controlled for initial levels of the response variable. Together, the latter two terms described the effects of spraying, with the main treatment effect testing for posttreatment differences between treated and control plots that were independent of initial levels of knapweed cover, and the treatment $\times$ pretreatment knapweed cover interaction testing for differences that varied in magnitude with initial levels of knapweed cover. Practically speaking, the main treatment effect addressed the possibility that 
picloram would have negative effects on some native taxa regardless of how much knapweed was initially present (i.e., nontarget effects), whereas the treatment $\times$ pretreatment knapweed interaction addressed the possibility that picloram's suppression of knapweed would lead to positive effects dependent on the initial abundance of knapweed (i.e., release effects). Thus, for plots initially containing knapweed, the overall treatment effect factored in both the main treatment effect and the treatment $\times$ pretreatment knapweed interaction (nontarget effects and release effects were both possible). In contrast, for plots with no initial knapweed, the treatment $X$ pretreatment knapweed interaction term reduced to zero and the overall treatment effect consisted of the main effect alone (release effects were not possible).

To depict overall treatment effects on native functional groups at differing baseline levels of knapweed invasion, we output least squares means and SEs for treated and control plots (PROC MIXED, LSMEANS statement; SAS Institute 2004). This procedure used the mixed model described above to estimate treatment means over a balanced population at specified values of model covariates. We set values of model covariates to represent three discrete points over the range of observed pretreatment invasion conditions in plots. Each of these specified points was defined by a fixed level of pretreatment knapweed cover and a corresponding fixed level of each pretreatment native response variable. Pretreatment knapweed cover was set to the following values: $0 \%$ (no invasion), $20 \%$ (moderate invasion), and $40 \%$ (high invasion). Corresponding pretreatment values of native response variables for each level of knapweed cover were derived using the previously reported correlation between each native response variable and knapweed cover (Ortega and Pearson 2005). Therefore, the specified values of pretreatment covariates depicted baseline declines in native functional groups associated with increasing knapweed invasion.

We tested for long-term effects of picloram application on spotted knapweed and cheatgrass, as evident in the sixth and final posttreatment year (2008), using a model parallel to that described for native functional groups. In addition, to consider background trends in spotted knapweed and cheatgrass unrelated to the herbicide treatment, we examined annual changes in cover of these species in control plots as measured in the current study (2003-2005 and 2008) relative to the initial sampling year (2000). In this model, we treated the response per plot and year as a repeated measure, entered the initial level of the variable as a covariate, and included a year $\times$ initial knapweed cover interaction to test for variation in annual trends by invasion level. To depict these trends, we output least squares means and SEs (PROC MIXED, LSMEANS statement; SAS Institute 2004) per year at the three discrete levels of initial knapweed cover defined above. To obtain least squares means for cheatgrass, the initial level of cheatgrass cover specified for each initial knapweed level (i.e., input values of the covariate) reflected the negative relationship between these two variables $\left(F_{1,381}=9.7, P=0.002\right)$.

\section{RESULTS}

Background levels of spotted knapweed in control plots changed substantially over the study period (Fig. 1A). Trends
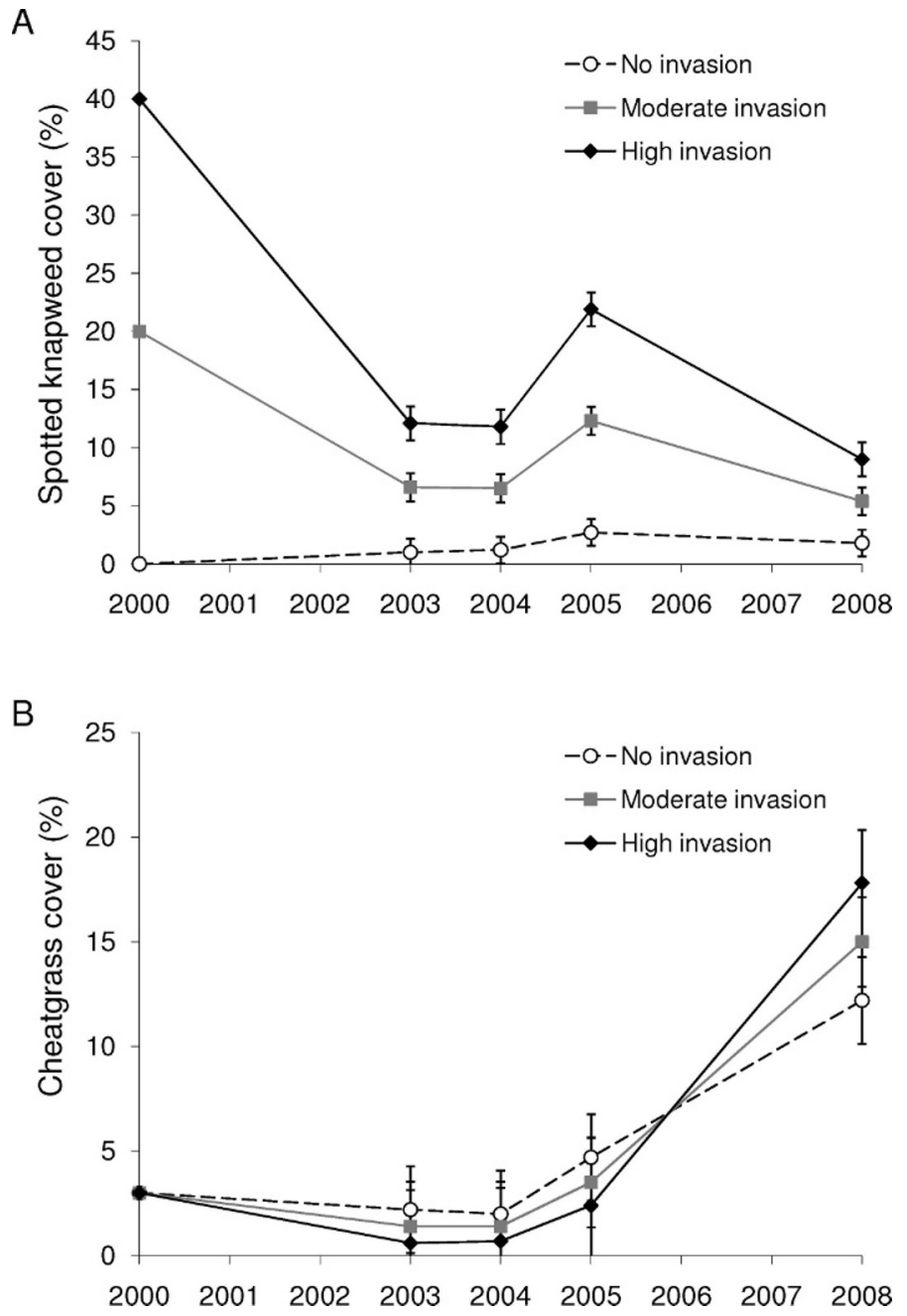

Figure 1. Background trends in A, spotted knapweed, and $\mathbf{B}$, cheatgrass, in untreated control plots $(n=208)$ at four western Montana grassland sites across sampling years, 2003-2005 and 2008, relative to the initial reference year, 2000 . Mean cover values $( \pm \mathrm{SE})$ per sampling year are given for three initial levels of spotted knapweed cover: $0 \%$ (no invasion), 20\% (moderate), and 40\% (high); reference levels of each invader in 2000 are also shown (see Methods).

from 2003 to 2008, corresponding to the posttreatment period, varied with initial invasion levels measured in 2000, the reference pretreatment year $\left(\mathrm{F}_{3,199}=48.3, P<0.001\right)$. In plots with no initial invasion ( $0 \%$ knapweed cover), mean knapweed levels increased slightly to reach a high near 3\% cover, whereas in plots with moderate and high initial invasion $(20 \%$ and $40 \%$ knapweed cover, respectively), mean levels declined $>70 \%$ by the final sampling year, falling below $10 \%$ cover (Fig. 1A). In contrast, background levels of cheatgrass in control plots increased $>$ fourfold between 2000 and 2008, remaining at $<3 \%$ mean cover midway through the sampling period before increasing to $>11 \%$ mean cover by the final year (Fig. 1B). Moreover, the magnitude of the cheatgrass increase varied with initial levels of spotted knapweed invasion, with steeper increases in plots with higher initial knapweed cover $\left(\mathrm{F}_{4,199}=4.5, P<0.002\right.$; Fig. 1B $)$.

Our analysis of treatment effects accounted for background changes in response variables by examining differences between 

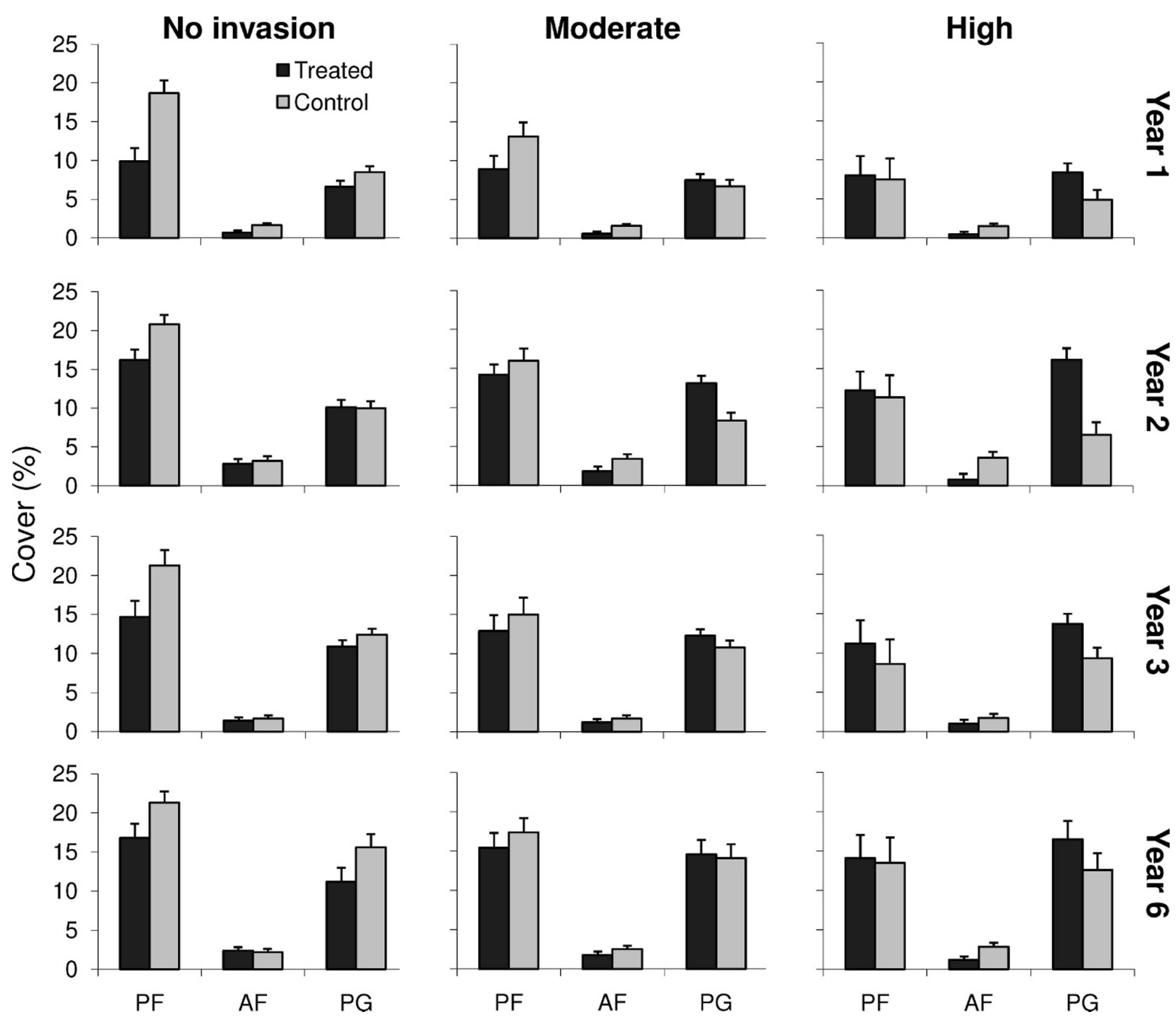

Figure 2. Overall effects of picloram application on percentage of cover of native functional groups, based on mixed model analysis of data from four pairs of grassland sites in western Montana. For each posttreatment year, 2003-2005 and 2008 (rows), mean values (+ SE) are given for treated $(n=208)$ and control plots $(n=208)$ at three baseline levels of invasion (columns) defined by pretreatment levels of spotted knapweed cover (see Methods): $0 \%$ (no invasion), 20\% (moderate), and 40\% (high). Functional groups are given as follows: AF indicates annual forbs; PF, perennial forbs; and $P G$, perennial grasses.

treated plots and control plots while accounting for initial pretreatment levels. This analysis showed that broadcast application of picloram suppressed knapweed over the longterm posttreatment period. In posttreatment year six (2008), mean knapweed cover in treated plots was reduced to $<4 \% \pm 1.21-1.45 \%$ SE across the range of initial invasion levels compared to $<10 \% \pm 1.17-1.37 \%$ cover in control plots, $a>60 \%$ reduction (main treatment effect: $F_{1,343}=5.1$, $P=0.02$ ), with the magnitude of this difference increasing gradually with the initial invasion level (treatment $\times$ pretreatment knapweed cover: $\mathrm{F}_{1,342}=13.0, P<0.001$ ). In contrast, herbicide treatment led to significant though small increases in cheatgrass over the long-term posttreatment period: in posttreatment year six, mean cheatgrass cover was $15.4 \% \pm 2.1 \%$
$\mathrm{SE}$ in treated plots compared to $12.2 \% \pm 2.07 \%$ SE in control plots (main treatment effect: $\mathrm{F}_{1,340}=4.8, P=0.03$ ), and the treatment effect did not vary with initial levels of knapweed invasion (treatment $\times$ pretreatment knapweed cover: $\left.\mathrm{F}_{1,341}=2.7, P=0.07\right)$.

\section{Effects on Native Cover}

In terms of cover, perennial forbs were the most prevalent group in control plots with no initial knapweed invasion, and showed the steepest decline with increasing baseline levels of the invader (Fig. 2; Ortega and Pearson 2005). Following picloram application, perennial forb cover was reduced in treated relative to control plots, primarily at the no-invasion level. The main treatment effect accounted for declines in 
Table 1. Local-scale effects of picloram application on cover and species richness of native functional groups in each of $3 \mathrm{yr}$ following treatment (2003-2005) and at $6 \mathrm{yr}$ posttreatment (2008), based on mixed model analysis of data from plots at four pairs of sites in western Montana. Treatment effects were divided into two components: the main treatment effect, testing for differences between treated and control plots that were independent of pretreatment spotted knapweed cover, and the treatment $\times$ knapweed interaction, testing for differences that varied in magnitude with pretreatment knapweed cover. Negative $\Delta$ values indicate treatment-related declines and positive values indicate treatment-related increases where $P<0.05$ (parentheses indicate $P<0.1$ ).

\begin{tabular}{|c|c|c|c|c|c|c|c|}
\hline & \multirow[b]{2}{*}{ Year } & \multicolumn{3}{|c|}{ Treatment } & \multicolumn{3}{|c|}{ Treatment $\times$ knapweed } \\
\hline & & $\Delta$ & $F^{1}$ & $P$ & $\Delta$ & $F^{2}$ & $P$ \\
\hline \multicolumn{8}{|l|}{ Cover } \\
\hline \multirow{4}{*}{$\begin{array}{l}\text { Perennial } \\
\text { forbs }\end{array}$} & 1 & - & 35.8 & $<0.001$ & + & 3.9 & 0.022 \\
\hline & 2 & - & 6.4 & 0.012 & & 0.9 & 0.42 \\
\hline & 3 & - & 14.7 & $<0.001$ & + & 3.3 & 0.038 \\
\hline & 6 & $(-)$ & 3.8 & 0.051 & & 0.6 & 0.56 \\
\hline \multirow{4}{*}{$\begin{array}{r}\text { Annual } \\
\text { forbs }\end{array}$} & 1 & - & 46.9 & $<0.001$ & & 0.4 & 0.68 \\
\hline & 2 & & 1.2 & 0.28 & - & 6.1 & 0.002 \\
\hline & 3 & & 1.6 & 0.21 & & 0.7 & 0.52 \\
\hline & 6 & & 0.8 & 0.37 & - & 7.3 & $<0.001$ \\
\hline \multirow{3}{*}{$\begin{array}{r}\text { Perennial } \\
\text { grasses }\end{array}$} & 1 & - & 7.7 & 0.006 & + & 6.0 & 0.003 \\
\hline & 2 & & 0.01 & 0.92 & + & 13.9 & $<0.001$ \\
\hline & 3 & $(-)$ & 3.6 & 0.059 & + & 8.0 & $<0.001$ \\
\hline \multicolumn{8}{|c|}{ Species richness } \\
\hline \multirow{4}{*}{$\begin{array}{l}\text { Perennial } \\
\text { forbs }\end{array}$} & 1 & - & 44.5 & $<0.001$ & $(+)$ & 2.6 & 0.076 \\
\hline & 2 & - & 59.7 & $<0.001$ & & 0.8 & 0.45 \\
\hline & 3 & - & 36.9 & $<0.001$ & + & 4.3 & 0.015 \\
\hline & 6 & - & 45.7 & $<0.001$ & & 0.06 & 0.94 \\
\hline \multirow{4}{*}{$\begin{array}{r}\text { Annual } \\
\text { forbs }\end{array}$} & 1 & - & 131.0 & $<0.001$ & & 1.6 & 0.2 \\
\hline & 2 & & 1.1 & 0.31 & - & 22.5 & $<0.001$ \\
\hline & 3 & & 0.0 & 0.97 & - & 5.7 & 0.004 \\
\hline & 6 & & 0.2 & 0.66 & - & 12.0 & $<0.001$ \\
\hline \multirow{4}{*}{$\begin{array}{r}\text { Perennial } \\
\text { grasses }\end{array}$} & 1 & & 0.1 & 0.71 & + & 8.8 & $<0.001$ \\
\hline & 2 & - & 7.5 & 0.007 & + & 8.8 & $<0.001$ \\
\hline & 3 & $(-)$ & 3.3 & 0.07 & + & 3.1 & 0.047 \\
\hline & 6 & - & 11.2 & $<0.001$ & + & 5.8 & 0.003 \\
\hline
\end{tabular}

${ }^{1}$ Years 1-3: $\mathrm{df}=1$ and 399-410; year 6: $\mathrm{df}=1$ and 339-342.

${ }^{2}$ Years 1-3: $d f=2$ and 302-409; year 6: $d f=2$ and 336-341.

perennial forb cover that were independent of pretreatment knapweed cover in the first three posttreatment years $(P<0.02)$, and marginally so in year six $(P=0.051$; Table 1$)$. Overall, at the no-invasion level, perennial forb cover in treated vs. control plots was reduced by $>20 \%$ across posttreatment years, to equal levels typically found at moderate or high levels of knapweed invasion (Fig. 2). Thus, effects of picloram application in noninvaded plots appeared to be substantial relative to baseline declines associated with increasing knapweed invasion. However, in plots initially invaded by knapweed, treatment-related declines in perennial forb cover described by the main treatment effect were countered by a positive treatment effect that increased in magnitude with pretreatment knapweed levels and was significant in posttreatment years one and three (treatment $\times$ pretreatment knapweed cover; $P<0.04$; Table 1). Therefore, at moderate and high invasion levels, differences in perennial forb cover between treated and control plots were minimal overall (Fig. 2).

Annual forbs were the least prevalent group as measured by cover in control plots with no invasion, and did not decline with increasing baseline cover of knapweed (Fig. 2; Ortega and
Pearson 2005). However, effects of picloram treatment on annual forb cover were evident in most posttreatment years, particularly in plots initially invaded by knapweed. In the first posttreatment year, the main treatment effect accounted for declines that were independent of pretreatment knapweed cover $(P<0.001$; Table 1$)$, resulting in a $>50 \%$ reduction in overall annual forb cover in treated vs. control plots across invasion levels (Fig. 2). However, this effect on annual forbs amounted to a difference of $<1 \%$ cover given the small stature of plants in this group. In years two and six, treatment-related declines were significant in invaded areas only and increased in magnitude with pretreatment knapweed levels (treatment $X$ pretreatment knapweed cover: $P \leq 0.002$; Table 1 ). In these years, overall annual forb cover in treated vs. control plots was depressed by $\geq 30 \%$ at the moderate invasion level and $\geq 59 \%$ at the high invasion level, again translating to relatively small differences in cover (Fig. 2).

Perennial grass cover tended to be moderate relative to other groups in control plots with no initial knapweed cover, and similarly showed moderate declines with increasing baseline levels of invasion (Fig. 2; Ortega and Pearson 2005). Effects of 
picloram application on perennial grass cover varied across baseline invasion levels. The main treatment effect accounted for declines that were independent of pretreatment knapweed cover in posttreatment years one and six $(P \leq 0.006$; Table 1) and marginally so in year three $(P=0.059$; Table 1$)$. At the noinvasion level, the result was a minor reduction in perennial grass cover in treated vs. control plots in corresponding years (Fig. 2). However, in invaded plots, this negative treatment effect was countered in all years by a positive treatment effect that increased in magnitude with pretreatment knapweed levels (treatment $\times$ pretreatment knapweed cover: $P \leq 0.003$; Table 1). At the moderate invasion level, the combination of treatment effects resulted in minimal difference in perennial grass cover between treated and control plots in most years (Fig. 2). However, at the high invasion level, perennial grass cover in treated vs. control plots increased by $\geq 59 \%$ in the first three posttreatment years and by $31 \%$ in year six to reach baseline levels found in areas with no knapweed (Fig. 2). Thus, treatment effects on perennial grass cover at the high invasion level appeared to overcome declines associated with knapweed invasion.

\section{Effects on Native Species Richness}

As found for cover, richness of perennial forb species tended to be high relative to other groups in control plots with no knapweed, and showed the steepest decline with increasing levels of the invader (Fig. 3; Ortega and Pearson 2005). In all posttreatment years, perennial forb richness was reduced in treated relative to control plots at most levels of initial invasion. The main treatment effect accounted for declines in perennial forb richness that were independent of pretreatment knapweed cover in all years $(P<0.001$; Table 1$)$. As a result, perennial forb richness in treated vs. control plots was reduced by approximately $30 \%$ in most cases to match levels found in high-invasion areas (Fig. 3). However, in posttreatment years one and three, this negative effect was dampened in invaded plots by a positive treatment effect that increased in magnitude with pretreatment knapweed levels (treatment $\times$ pretreatment knapweed cover: $P<0.08$, Table 1$)$. Therefore, differences between treated and control plots were not evident at the high invasion level in years one and three. In remaining cases, effects of picloram application on perennial forb richness appeared to be greater than baseline declines associated with increasing knapweed invasion.

Species richness of annual forbs was generally moderate relative to other groups in control plots with no knapweed (Fig. 3). As found for cover, richness of annual forbs did not decline with increasing baseline cover of knapweed (Fig. 3; Ortega and Pearson 2005). However, in all posttreatment years, annual forb richness was reduced in treated relative to control plots at most levels of initial invasion. In the first posttreatment year, the main treatment effect accounted for declines that were independent of pretreatment knapweed cover $(P<0.001$; Table 1$)$, resulting in a $\geq 50 \%$ overall reduction in annual forb richness in treated vs. control plots across invasion levels (Fig. 3). In subsequent years, treatmentrelated declines were significant in invaded areas only and increased in magnitude with pretreatment knapweed levels (treatment $\times$ pretreatment knapweed cover: $P \leq 0.004$; Ta- ble 1). In these years, species richness of annual forbs in treated vs. control plots was depressed by $\geq 24 \%$ at the moderate invasion level and $\geq 43 \%$ at the high invasion level (Fig. 3).

Species richness of perennial grasses tended to be lower than species richness of forb groups in control plots with no knapweed, and showed only slight declines with increasing baseline levels of invasion (Fig. 3; Ortega and Pearson 2005). Following picloram application, changes in perennial grass richness in treated relative to control plots varied by invasion level and year, but tended to be small relative to treatment effects on other groups. The main treatment effect, accounting for declines that were independent of initial knapweed cover, was significant in posttreatment years two and six $(P \leq 0.006$; Table 1$)$ and marginally so in year three $(P=0.07$; Table 1$)$, and resulted in a minor reduction in perennial grass richness in treated vs. control plots at the no-invasion level (Fig. 3). In invaded plots, this negative treatment effect was countered in all years by a positive treatment effect that increased in magnitude with pretreatment knapweed levels (treatment $\times$ pretreatment knapweed cover: $P<0.05$; Table 1). At the moderate invasion level, the combination of treatment effects on perennial grass richness resulted in minimal difference between treated and control plots in most years (Fig. 3). However, at the high invasion level only, perennial grass richness in treated vs. control plots increased by $>25 \%$ in the first two posttreatment years, enough to temporarily overcome the weak declines associated with knapweed invasion (Fig. 3).

\section{DISCUSSION}

Weed control efforts implicitly assume that suppression of the target invader will relieve invader impacts to benefit native plant communities and improve rangeland conditions, but the effects of such management actions are usually not examined beyond the target invader or a few forage species (Sheley et al. 2006; Smith et al. 2006; Flory and Clay 2009). As seen in numerous studies (e.g., Rice et al. 1997; Sheley et al. 2000, 2006), the broadcast picloram treatment applied in our study effectively suppressed spotted knapweed. Declines in knapweed cover in treated relative to control plots were evident in the $3 \mathrm{yr}$ following spraying (Ortega and Pearson 2010) as well $6 \mathrm{yr}$ posttreatment. Furthermore, target invader suppression appeared to have positive effects on native perennial forbs and grasses that increased in magnitude with initial invasion levels in plots. These positive treatment effects likely signify at least some release of perennial taxa from impacts of knapweed, as experiments have shown that established native plants can readily respond to removal of neighboring knapweed plants (Lesica and Shelly 1996; Callaway et al. 1999; Ridenour and Callaway 2001). However, for perennial forbs, release effects were countered by negative treatment effects that were independent of initial knapweed levels. Negative effects of picloram application were also evident for annual forbs, especially in the first posttreatment year. These negative effects on native forbs likely reflect limitations in herbicide selectivity. Picloram is a growth regulator that injures or kills dicotyledonous plants in many common plant families, primarily impacting forbs when used at rates targeting knapweed and 

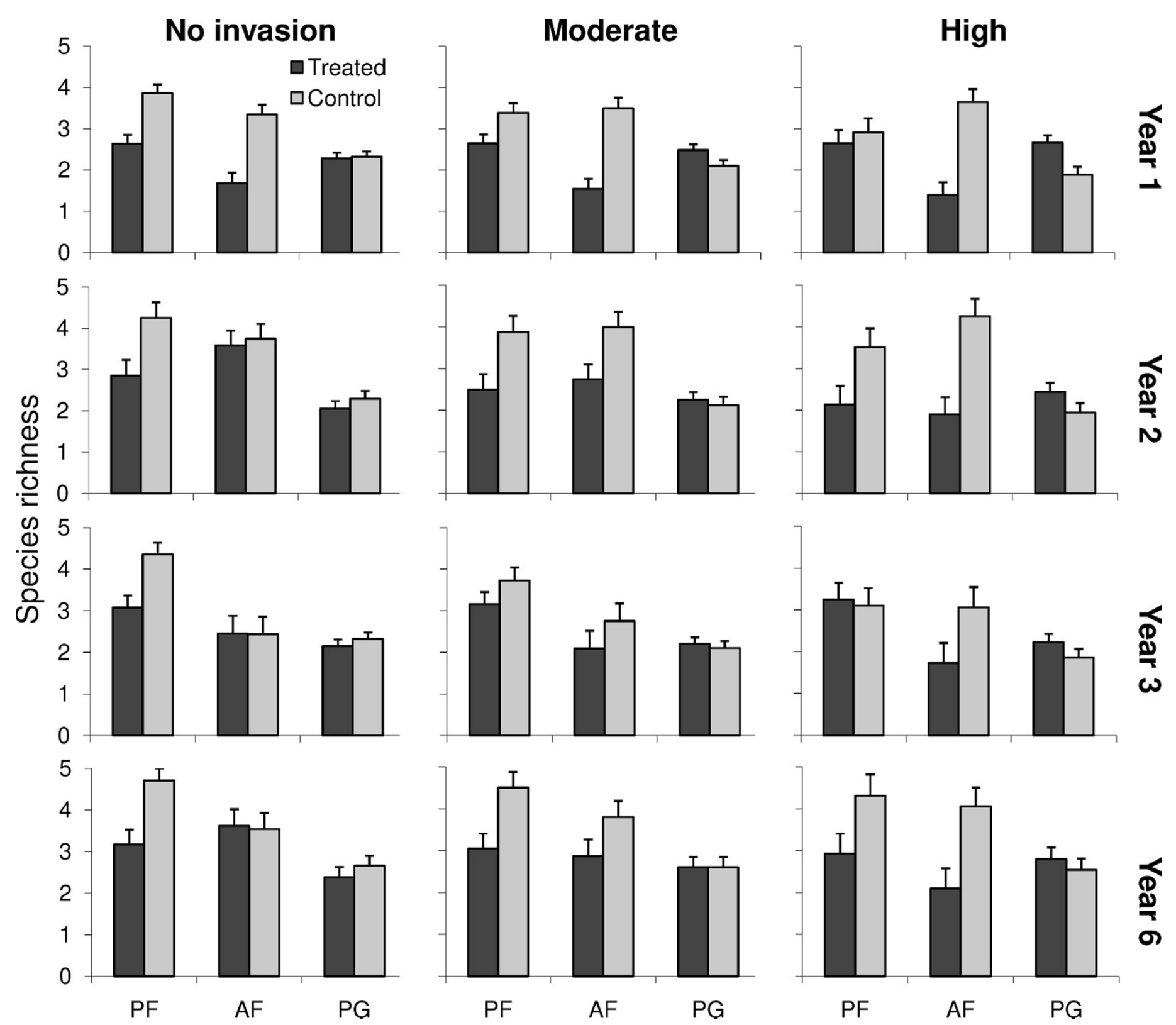

Figure 3. Overall effects of picloram application on species richness of native functional groups, based on mixed model analysis of data from four pairs of grassland sites in western Montana. For each posttreatment year, 2003-2005 and 2008 (rows), mean values (+ SE) are given for treated ( $n=208$ ) and control plots $(n=208)$ at three baseline levels of invasion (columns) defined by pretreatment levels of spotted knapweed cover (see Methods): $0 \%$ (no invasion), 20\% (moderate), and 40\% (high). Functional groups are given as follows: AF indicates annual forbs; PF, perennial forbs; and PG, perennial grasses.

other common weeds (Rice et al. 1997; Rice and Toney 1998; Rinella et al. 2009).

Due to these opposing treatment effects, picloram application resulted in complex shifts in prevalence of native functional groups in plots that differed across baseline levels of knapweed invasion. At the no-invasion level, perennial forbs, the dominant group, appeared to be most sensitive to treatment, with cover and species richness declining to levels typical of plots with moderate to high knapweed invasion. At the moderate invasion level, treatment effects on cover of native functional groups were relatively weak, but species richness of both annual and perennial forbs saw treatment declines that equaled or exceeded those associated with knapweed invasion.
At the high invasion level, annual forb richness showed strong treatment declines, as did perennial forb richness in some years, while perennial grass cover showed strong treatment increases and rose to levels found in no-invasion plots.

Observed treatment effects on native functional groups largely persisted through the sixth and final posttreatment sampling year. Although some studies have found that effects of picloram treatment appear to dissipate over this time frame (Rice et al. 1997; Rice and Toney 1998), another study (Rinella et al. 2009) found that negative effects of picloram treatment on native forb prevalence remained evident $16 \mathrm{yr}$ following application, indicating that long-term impacts on native populations can occur. In addition, previous work has 
documented effects of picloram on important native demographic variables that may contribute to the longevity of treatment effects. For example, picloram has been shown to reduce seed production, recruitment, and survival of the dominant perennial forb, arrowleaf balsamroot (Crone et al. 2009; Ortega and Pearson 2010). Conversely, positive effects of picloram treatment on the dominant perennial grass, bluebunch wheatgrass, have been shown to extend beyond cover to seed production (Ortega and Pearson 2010). Such effects on demographic variables could translate to long-term changes in native plant populations, particularly if treatments are applied repeatedly (Crone et al. 2009; Ortega and Pearson 2010) as is often done to counter reinvasion (e.g., Rice et al. 1997; Tyser et al. 1998; USDA Forest Service 2007, 2008).

Suppression of spotted knapweed typically subsides 3-5 yr following picloram application, after which the invader may recover to initial levels (Rice et al. 1997; Sheley et al. 2000). In our study, recovery of knapweed may have been slowed due to background declines in this species unrelated to treatment (Fig. 1). Similar declines in spotted knapweed were observed at other untreated sites in western Montana over this time period, suggesting that concurrent drought conditions may have impacted the weed (Sturdevant et al. 2006; Pearson and Fletcher 2008). Although the drought could have also affected native species and their response to treatment, we note that background levels of native functional groups measured in untreated plots were relatively stable over the study period (Fig. 2).

Observed effects of broadcast picloram application on native functional groups could have system-level consequences. The treatment successfully suppressed spotted knapweed, an undesirable rangeland invader with many documented impacts on grassland ecosystems (e.g., Sheley et al. 2000; Ortega and Pearson 2005). Resultant increases in native perennial grasses may alleviate baseline impacts of spotted knapweed on dependent system properties, e.g., by restoring grass forage for elk and livestock (Thompson 1996). At the same time, broadcast picloram application, when used alone, may compound knapweed's impacts by reducing cover and localscale diversity of native forbs. Several studies have shown that broadleaf herbicide treatments depress plant species diversity, at least temporarily (Rice et al. 1997; Rice and Toney 1998; Sheley et al. 2006). However, most studies considering diversity and other measures of species turnover have examined only coarse metrics of community change by lumping together native and exotic species across functional groups and invasion levels, making implications for restoration less clear. Species diversity, as measured at local scales, is known to influence resistance to invasion, productivity, and numerous other system properties (Balvanera et al. 2006; Cardinale et al. 2006; Maron and Marler 2007). Moreover, native forbs may be particularly important in maintaining these properties within grassland communities, as indicated not only by their high species richness but also by their high relative abundance and diversity of functional traits (Smith and Knapp 2003; Pokorny et al. 2004, 2005; Rinella et al. 2007). Declines in native forbs may also affect wildlife species given that native forbs provide key resources for an array of herbivores including sage grouse (Centrocercus spp.; Crawford et al. 2004) and pronghorn antelope (Antilocapra americana; Mitchell and Smoliak 1971).
Broadleaf herbicide application may also promote increases in exotic grasses that degrade rangeland conditions. Cheatgrass, the secondary exotic on our sites prior to treatment, is particularly problematic in western North America. This invader is known to proliferate in response to removal of perennial species, displace native species, provide relatively poor forage for wildlife and livestock, and increase fire frequency (DiTomaso 2000; Chambers et al. 2007; Vasquez et al. 2008). The picloram treatment applied in our study caused large increases in cheatgrass cover in the first $3 \mathrm{yr}$ after spraying, a period when background levels of the invader in control plots remained low relative to initial levels (Ortega and Pearson 2010). During this period, treatment effects on cheatgrass were greatest in areas with high initial knapweed invasion, where average cheatgrass cover was elevated $>10$-fold in treated relative to control plots. A field experiment in which individual spotted knapweed plants were selectively removed also showed that suppression of the primary invader can release cheatgrass (Ortega and Pearson 2010). This negative relationship between invaders may in part explain background changes in cheatgrass observed over the long-term study period. While knapweed cover in control plots declined between 2000 and 2008, cheatgrass cover increased, especially in those plots with high initial knapweed cover, i.e., where knapweed declines were greatest (Fig. 1). Although differences between treated and control plots were still evident in the final sampling year for both invaders, knapweed cover in both types of plots was low relative to initial levels whereas cheatgrass cover was high relative to initial levels. In other words, once background changes in cover were accounted for, treatment effects on knapweed and cheatgrass amounted to relatively small differences between treated and control plots by the end of the study. Even so, our long-term results emphasize the link between declines in the primary invader and increases in the secondary invader, a pattern seen in many weed control studies (Pearson and Ortega 2009). In short, broadleaf herbicide application may facilitate increases in cheatgrass, and such effects may persist if suppression of the target weed is sustained (Ortega and Pearson 2010).

\section{IMPLICATIONS}

Broadleaf herbicides are a primary method of weed control in rangelands of North America, and the treatment examined in our study, broadcast spraying of picloram, is particularly common (e.g., Shepard et al. 2004). Broadcast spraying is a cost-efficient means of suppressing invaders over large areas but is insensitive to variability in local-scale conditions. Our study specifically shows that the treatment response can vary with the initial level of target weed invasion, indicating that more localized application methods may enable managers to have increased control over outcomes. For example, spot-spraying weed patches would minimize nontarget effects, leaving surrounding areas intact while allowing for release of native taxa tolerant of the herbicide. Given that nontarget effects on native forbs can persist beyond typical application frequencies, follow-up treatments should be delayed as long as possible unless they are focused on residual or recovering weed patches. Our study underscores that even lateseason applications can incur nontarget impacts on native forbs when a persistent herbicide such as picloram is used. Nontarget 
effects may be reduced by using herbicides other than picloram, although this may also reduce target invader control (Endress et al. 2008). When broadleaf herbicides are applied at sites where undesirable invasive grasses such as cheatgrass are present, integrated approaches (e.g., sowing seeds of herbicide-tolerant native species) may be needed to reduce the risk of secondary invasion and promote community recovery (Tyser et al. 1998; Sheley et al. 2006; Endress et al. 2008).

Our study underscores that weed control measures alone are unlikely to alleviate overall impacts of invasive plants on native taxa. The broadcast picloram treatment succeeded in suppressing the target invader, spotted knapweed. Although suppression of knapweed released native taxa from invader impacts to some degree, the strength of release effects varied by functional group and the initial level of invasion. Treatment restored native perennial grass cover to baseline no-invasion levels, but only in plots where knapweed levels were initially high. Release effects on native perennial forb cover were countered by nontarget effects of spraying, overall resulting in neutral treatment effects at moderate and high invasion levels but negative effects at the no-invasion level. At all invasion levels, picloram application reduced species richness of native forbs, compounding impacts of the target invader on these taxa. Treatment also promoted increases in cheatgrass, a problematic secondary invader. Most treatment side effects were persistent, and would likely be reinforced by repeated applications. Given that rangeland health depends on restoring and maintaining diverse plant communities, broadleaf herbicides such as picloram should be applied selectively in conjunction with measures designed to promote recovery of plant functional groups and resistance to recurring weed invasions.

\section{ACKNOWLEDGMENTS}

We appreciate the comments of P. Lesica, S. Sutherland, and anonymous reviewers on earlier drafts of this work. R. King provided statistical advice. We thank L. Priestman, R. Anderson, A. Seibel, K. Bovee, L. McIntyre, J. Roberts, and J. Cornwell for their hard work in the field. A. Kulla and C. Stewart of the Lolo National Forest provided logistical support.

\section{LITERATURE CITED}

Balvanera, P., A. B. Pfisterer, N. Buchmann, J. He, T. Nakashizuka, D. Raffaelli, and B. ScHmidz. 2006. Quantifying the evidence for biodiversity effects on ecosystem functioning and services. Ecology Letters 9:1146-1156.

Callaway, R. M., T. H. Deluca, and W. M. Belliveau. 1999. Biological-control herbivores may increase competitive ability of the noxious weed Centaurea maculosa. Ecology 80:1196-1201.

Cardinale, B. J., D. S. Srivastava, J. E. Duffy, J. P. Wright, A. L. Downing, M. Sankaran, and C. Jouseau. 2006. Effects of biodiversity on the functioning of trophic groups and ecosystems. Nature 443:989-992.

Chambers, J. C., B. A. Roundy, R. R. Blank, S. E. Meyer, and A. Whittaker. 2007. What makes Great Basin sagebrush ecosystems invasible by Bromus tectorum? Ecological Monographs 77:117-145.

Crawford, J. A., R. A. Olson, N. E. West, J. C. Mosley, M. A. Schroeder, T. D. Whitson, R. F. Miller, M. A. GregG, and C. S. Boyd. 2004. Ecology and management of sage-grouse and sage-grouse habitat. Journal of Range Management 57:2-19.

Crone, E. E., M. Marler, and D. E. Pearson. 2009. Non-target effects of broadleaf herbicide on native perennial forbs: a demographic framework for assessing and minimizing impacts. Journal of Applied Ecology 46:673-682.
Ditomaso, J. M. 2000. Invasive weeds in rangelands: species, impacts, and management. Weed Science 48:255-265.

Dow AgroSciences. 2001. Tordon 22K. Specimen Label. New York, NY, USA: C \& P Press. 7 p.

Endress, B. A., C. G. Parks, B. J. Naylor, and S. R. Radosevich. 2008. Herbicide and native grass seeding effects on sulfur cinquefoil (Potentilla recta)-infested grasslands. Invasive Plant Science and Management 1:50-58.

FLoRY, S. L., AND K. CLAY. 2009. Invasive plant removal method determines native plant community responses. Journal of Applied Ecology 46:434-442.

Hempy-Mayer, K., and D. A. PYke. 2008. Defoliation effects on Bromus tectorum seed production: implications for grazing. Rangeland Ecology and Management 61:116-123.

Lesica, P., And J. S. Shelly. 1996. Competitive effects of Centaurea maculosa on the population dynamics of Arabis fecunda. Bulletin of the Torrey Botanical Club 123:111-121.

Mack, R. N., D. Simberloff, W. M. Longsdale, H. Evans, M. Clout, and F. H. Bazzaz. 2000. Biotic invasions: causes, consequences, and control. Ecological Applications 10:698-710.

Maron, J. L., AND M. J. Marler. 2007. Native plant diversity resists invasion at both low and high resource levels. Ecology 88:2652-2661.

Mitchell, G. J., And S. Smoliak. 1971. Pronghorn antelope range characteristics and food habits in Alberta. Journal of Wildlife Management 35:238-250.

Mueggler, W. F., and W. L. Stewart. 1980. Grassland and shrubland habitat types of western Montana. Ogden, UT, USA: USDA Forest Service, General Technical Report INT-66. $151 \mathrm{p}$.

Ortega, Y. K., and D. E. Pearson. 2005. Strong versus weak invaders of natural plant communities: assessing invasibility and impact. Ecological Applications 15:651-661.

Ortega, Y. K., and D. E. Pearson. 2010. Effects of picloram application on community dominants vary with initial levels of spotted knapweed (Centaurea stoebe) invasion. Invasive Plant Science and Management 3:70-80.

Pearson, D. E., and R. J. Fletcher, JR. 2008. Mitigating exotic impacts: restoring native deer mouse populations elevated by an exotic food subsidy. Ecological Applications 18:321-334.

Pearson, D. E., and Y. K. Ortega. 2009. Managing invasive plants in natural areas: moving beyond control. In: F. Columbus [ED.]. Weeds: management, economic impacts and biology. Hauppauge, NY, USA: Nova Publishers. 1-21.

Pokorny, M. L., R. L. Sheley, T. J. Svejcar, and R. E. Engel. 2004. Plant species diversity in a grassland plant community: evidence for forbs as a critical management. Western North American Naturalist 64:219-230.

Pokorny, M. L., S. L. Sheley, C. A. Zabinski, R. E. Engel, T. J. Svejcar, and J. J. Bonkowski. 2005. Plant functional group diversity as a mechanism for invasion resistance. Restoration Ecology 13:448-459.

Reever Morghan, K. J., E. A. Leger, and K. J. Rice. 2003. Clopyralid effects on yellow starthistle (Centaurea solstitialis) and nontarget species. Weed Science $51: 596-600$.

RICE, P. M., AND J. C. TONEY. 1998. Exotic weed control treatments for conservation of fescue grassland in Montana. Biological Conservation 85:83-95.

Rice, P. M., J. C. Toney, D. J. Bedunah, and C. E. Carlson. 1997. Plant community diversity and growth form responses to herbicide applications for control of Centaurea maculosa. Journal of Applied Ecology 34:1397-1412.

Ridenour, W. M., and R. M. Callaway. 2001. The relative importance of allelopathy in interference: the effects of an invasive weed on a native bunchgrass. Oecologia 126:444-450

Rinella, M. J., B. D. Maxwell, P. K. Fay, T. Weaver, and R. L. Sheley. 2009. Control effort exacerbates invasive species problem. Ecological Applications 19:155-162.

Rinella, M. J., M. L. Pokorny, and R. Rekaya. 2007. Grassland invader response to realistic changes in native species richness. Ecological Applications 17:1824-1831.

Samuel, L. W., D. R. Kirby, J. E. Norland, and G. L. Anderson. 2008. Leafy spurge suppression by flea beetles in the Little Missouri Drainage Basin, USA. Rangeland Ecology \& Management 61:437-443.

SAS InStITUTE. 2002. Mixed models analyses using the SAS system course notes. Cary, NC, USA: SAS Institute Inc. 494 p. 
SAS Institute. 2004. SAS/STAT user's guide, version 9.1. Cary, NC, USA: SAS Institute Inc. $5124 \mathrm{p}$.

Sheley, R. L., C. A. Duncan, M. B. Halstvedt, and J. S. Jacobs. 2000. Spotted knapweed and grass response to herbicide treatments. Journal of Range Management 53:176-182.

Sheley, R. L., J. S. Jacobs, and M. F. Carpinelli. 1998. Distribution, biology, and management of diffuse knapweed (Centaurea diffusa) and spotted knapweed (Centaurea maculosa). Weed Technology 12:353-362.

Sheley, R. L., J. M. Mangold, And J. L. Anderson. 2006. Potential for successional theory to guide restoration of invasive-plant dominated rangeland. Ecological Monographs 76:365-379.

Shepard, J. P., J. Creighton, and H. Duzan. 2004. Forestry herbicides in the United States: an overview. Wildlife Society Bulletin 32:1020-1027.

Smith, M. D., and A. K. Knapp. 2003. Dominant species maintain ecosystem function with non-random species loss. Ecology Letters 6:509-517.

Smith, R. G., B. D. Maxwell, F. D. Menalled, and L. J. Rew. 2006. Lessons from agriculture may improve the management of invasive plants in wildland systems. Frontiers in Ecology and the Environment 4:428-434.

Stevens, D. R. 1966. Range relationships of elk and livestock, Crow Creek Drainage, Montana. Journal of Wildlife Management 30:349-363.

Sturdevant, N., S. Kegley, Y. Ortega, and D. Pearson. 2006. Evaluation of establishment of Cyphocleonus achates and its potential impact on spotted knapweed. Missoula, MT, USA: USDA Forest Service, USDA FS FHP General Technical Report 06-08. 9 p.
Tabachick, B. G., and L. S. Fidell. 1989. Using multivariate statistics. New York, NY, USA: HarperCollins. 746 p.

Thompson, M. J. 1996. Winter foraging response of elk to spotted knapweed removal. Northwest Science 70:10-19.

Travnicek, A. J., R. G. Lym, and C. Prosser. 2005. Fall-prescribed burn and springapplied herbicide effects on Canada thistle control and soil seedbank in a northern mixed-grass prairie. Rangeland Ecology \& Management 58:413-422.

Tyser, R. W., J. M. Asebrook, R. W. Potter, and L. L. Kurth. 1998. Roadside revegetation in Glacier National Park, USA: effects of herbicide and seeding treatments. Restoration Ecology 6:197-206.

USDA Forest Service. 2001. Big game winter range and burned area weed management on the Lolo National Forest. Final Environmental Impact Statement. Missoula, MT, USA: Lolo National Forest. 391 p.

USDA Forest Service. 2007. Kootenai invasive plant management project. Final Environmental Impact Statement. Libby, MT, USA: Kootenai National Forest. $231 \mathrm{p}$.

USDA Forest SERvice. 2008. Integrated weed management on the Lolo National Forest. Final Environmental Impact Statement. Missoula, MT, USA: Lolo National Forest. $304 \mathrm{p}$.

Vasquez, E., R. Sheley, and T. Svejcar. 2008. Nitrogen enhances the competitive ability of cheatgrass (Bromus tectorum) relative to native grasses. Invasive Plant Science and Management 1:287-295.

Watson, A. K., and A. J. Renney. 1974. The biology of Canadian weeds. 6. Centaurea diffusa and C. maculosa. Canadian Journal of Plant Science 54:687-701. 